\title{
Pengaruh Penggunaan Media Worksheet terhadap Hasil Belajar Siswa Sekolah Menengah
}

\author{
Jauhara Dian Nurul Iffah \\ Program Studi Pendidikan Matematika, STKIP PGRI Jombang \\ Jalan Pattimura III no 20, Sengon, Jombang, Indonesia \\ jauharadian.stkipjb@gmail.com
}

Artikel diterima: 10-07-2020, direvisi: 14-12-2020, diterbitkan: 31-01-2021

\begin{abstract}
Abstrak
Penelitian ini dilatar belakangi oleh kurangnya penggunaan media pembelajaran serta pentingnya media pembelajaran sebagai alat bantu bagi siswa dalam memahami materi. Media yang disebut worksheet merupakan lembar kerja yang berisi ringkasan materi dan kata kunci materi untuk memudahkan siswa memunculkan kembali hubungan yang diperlukan untuk menyelesaikan soal. Penelitian ini bertujuan untuk mengetahui ada tidaknya pengaruh worksheet terhadap hasil belajar siswa. Jenis penelitian adalah kuantitatif dengan desain pre test - post test. Sampel penelitian ini siswa kelas VIIIA MTs Salafiyah Syafi'iyah Tebuireng Jombang berjumlah 31 siswa. Materi yang digunakan adalah luas permukaan serta volume bangun Kubus dan Balok dengan isntrumen penelitian worksheet dan soal tes. Teknik analisis data menggunakan uji normalitas dan selanjutnya uji hipotesis menggunakan statistik uji-t dengan $\alpha=0,05$. Hasil penelitian menunjukkan bahwa terdapat pengaruh penggunaaan media worksheet terhadap hasil belajar siswa kelas VIIIA pada materi Kubus dan Balok. Sehingga worksheet dapat dijadikan alternatif media pembelajaran untuk materi Kubus dan Balok.

Kata Kunci: Hasil Belajar, Media Worksheet, Siswa Sekolah Menengah

\section{The Effect of Using Worksheet Media on Middle School Student Learning Outcomes}

Abstract

This research is motivated by the lack of use of instructional media and the importance of learning media as a tool for students in understanding the material. The media called a worksheet is a worksheet that contains a summary of the material and keywords of the material to make it easier for students to bring back the relationships needed to solve the problem. This study aims to determine whether the worksheet has an effect on student learning outcomes. This type of research is quantitative with a pre test - post test design. The sample of this research was students of class VIIIA MTs Salafiyah Syafiliyah Tebuireng Jombang totaling 31 students. The material used is the surface area and volume of cubes and blocks with research instruments worksheets and test questions. The data analysis technique used the normality test and then the hypothesis test used the $t$-test statistic with $\alpha=0.05$. The results showed that there was an effect of the use of worksheet media on the learning outcomes of class VIIIA students on cubes and blocks. So that worksheets can be used as an alternative learning media for cubes and blocks.

Keywords: Learning Outcomes, Media Worksheets, Middle School Students
\end{abstract}




\section{Pendahuluan}

Beberapa bagian penting dalam bidang ilmu pengetahuan adalah ilmu matematika. Siswa seharusnya dapat memahami konsep-konsep matematika dan dapat menggunakan konsep dalam pemecahan masalah (Afriansyah, 2016; Suryani, Jufri, \& Putri, 2020). Sehingga siswa tidak hanya menguasai materi namun juga dapat menggunakan materi tersebut dalam konteks kehidupan. Poin ini senada dengan prinsip pembelajaran pada kurikulum 2013 yang menyatakan pembelajaran bergeser tidak hanya dengan berbasis konten, namun juga berbasis kompetensi (Kemendikbud, 2013; Luritawaty, 2019; Suharyono \& Rosnawati, 2020).

Penguasaan konsep siswa terhadap matematika akan membuat siswa mampu menerapkan konsep tersebut dalam pemecahan masalah. Kemampuan siswa dalam menyelesaikan masalah akan membantu siswa dalam mamahami konsep kunci yang lain (NCTM, 2000; Fitri, Aima, \& Muhlisin, 2017). Suatu konsep kunci merupakan sebuah konsep dengan keistimewaan, yang berarti konsep itu digunakan sebagai kunci dan kode yang menghubungkan ke konsep lain (Rizkianto \& Santosa, 2017). Pemecahan masalah juga menjadi dasar keberhasilan siswa dalam belajar matematika (Novotná, Jarmila, Eisenmann, Přibyl, Ondrušová, \& Břehovský, 2012). Sehingga siswa sejak awal harus diajarkan tentang penyelesaian masalah.
Langkah pembelajaran yang disusun dalam proses pembelajaran diharapkan banyak memunculkan aktivitas-aktivitas yang menghasilkan siswa tdak hanya memahami materi tetapi juga siswa dapat menggunakan materi itu untuk memecahkan masalah baik dalam matematika maupun yang lain. Tahapan menyelesaikan masalah memiliki tahap yang terstruktur dan harus diikuti secara sistematis oleh siswa (Afriansyah, 2016).

Hal yang dapat mempengaruhi hasil siswa dalam belajar adalah kegiatan yang ada dalam proses belajar mengajar itu sendiri. Guru dapat membuat kegiatan yang melibatkan siswa dalam belajar sehinnga siswa menjadi merasa lebih mudag dalam belajar. Sehubungan dengan hal tersebut guru harus mampu untuk membuat pembelajaran yang memunculkan adanya interaksi anatra guru dan siswa (Winkel, 2007).

Pembelajaran adalah proses interaksi peserta didik dengan pendidik dan sumber belajar pada satu lingkungan belajar (Presiden Rl, 2003). Oleh karena itu ada lima jenis interaksi yang dapat berlangsung dalam proses pembelajaran, yaitu : a) Interaksi antara guru dan siswa, b) Interaksi antara sesama siswa atau antar sejawat, c) Interaksi antar siswa dengan narasumber, d) Interaksi siswa bersama guru dengan sumber belajar yang sengaja dikembangkan, e) Interaksi siswa bersama guru dengan lingkungan sosial dan alam.

Proses belajar dan mengajar adalah hal yang saling terkait. Belajar sendiri adalah 
proses yang dilakukan oleh siswa sebagai orang yang menerima materi dan mengajar adalah proses yang dilakukan oleh guru untuk mentransfer materi. Proses ini melibatkan adanya interaksi antara guru, siswa dan lingkungan. Belajar dikonseptualisasikan sebagai partisipasi dalam praktek-praktek sosial yang mengembangkan profesionalitas guru, keterlibatan siswa dan orang yang berada dalam praktek pembelajaran tersebut (Iffah, Sutawidjaja, \& Sa'dijah, 2015; Ma'ruf, Syafii, \& Kusuma, 2019; Yunita, Juwita, \& Kartika, 2020). Sehingga sangat erat kaitannya antara kemampuan guru dalam mengajar, kemampuan siswa dengan hasil belajar yang diperoleh.

Menurut Gagne (Sanjaya, 2011) mengajar atau teaching merupakan bagian dari pembelajaran (instruction), dimana peran guru lebih ditekankan kepada bagaimana merancang berbagai sumber dan fasilitas yang tersedia untuk digunakan atau dimanfaatkan siswa dalam mempelajari sesuatu. Ketika proses pembelajaran, terdapat metode mengajar yang merupakan cara guru dalam menyampaikan materi dan media pembelajaran yang merupakan alat yang digunakan guru untuk membantunya dalam mengajar (Herawati \& Nurhayati, 2019). Serta evaluasi untuk melihat tujuan pembelajaran sudah tercapai atau belum.

Interaksi antara guru dan siswa dalam pembelajaran terutama membentuk lingkungan sosial yang kondusif menjadi hal yang penting untuk dipertimbangkan oleh guru (Iffah dkk., 2015; Lubis, Harahap, \& Nasution, 2019; Robiana, \& Handoko, 2020).

Hubungan yang positif antara interaksi guru, siswa, motivasi siswa akan membuat peningkatan perolehan siswa dalam pembelajaran. Selain itu, adanya media pembelajaran sebagai salah satu upaya untuk meningkatkan proses interaksi gurusiswa dan lingkungan belajarnya. Oleh sebab itu, fungsi utama dari media pembelajaran adalah sebagai alat bantu mengajar, yakni menunjang penerapan metode mengajar yang dipergunakan guru, yang selanjutnya diharapkan dapat mempertinggi hasil belajar yang dicapainya (Sudjana \& Rivai, 2010; Nst \& Rahmi, 2017; Setiawan \& Prihatnani, 2020).

Manfaat media pembelajaran diantaranya adalah (Suwarsih, 2018; Lisnani \& Pranoto, 2020; Hodiyanto, Darma, \& Putra, 2020): a) siswa lebih termotivasi karena pembeajaran menjadi lebih menarik; b) materi disajikan lebih bermakna sehingga siswa dapat lebih memahami materi; c) guru dapat membuat variasi metode mengajar yang lebih banyak; d) siswa menjadi lebih aktif dalam pemebelajaran. Selain itu, tahap berpikir manusia mengikuti tahap perkembangan dimulai dari berpikir konkret menuju berpikir abstrak, dimulai dari berpikir sederhana menuju berpikir kompleks (Rahmatina, 2017; Afriansyah, dkk., 2020; Nursyahidah, dkk., 2020). Adanya media pembelajaran erat 
kaitannya dengan tahapan berpikir harus dijawab oleh siswa (Lisnani \& tersebut karena melalui media Asmaruddin, 2018; Prabawati, Herman, \& pembelajaran hal-hal yang abstrak dapat Turmudi, 2019). Dalam proses dikongkretkan dan hal-hal yang kompleks pembelajaran matematika, worksheet dapat disederhanakan (Sudjana \& Rivai, bertujuan untuk menemukan konsep atau 2010; Florayu, Isnaini, \& Testiana, 2017).

Kriteria penggunaan media pembelajara diantaranya adalah kesesuaian dengan tujuan pembelajaran, materi, kemudahan mendapatkan media, keterampilan guru dalam menggunakannya, ketersediaan waktu dan sesuai dengan tingkat berpikir siswa. Sehingga guru dapat lebih mudah menggunakan media mana yang dianggap tepat untuk membantu mempermudah tugasnya sebagai pengajar. Dapat disimpulkan bahwa adanya media dalam pembelajaran adalah sebagai alat untuk memudahkansiswa memahami materi, memunculkan masalah baru untuk dikaji dan diselesaiakn dalam proses belajarnya, sebagai sumber belajar sehingga siswa dapat memperoleh informasi baru melalui media tersebut. Namun media sebagai alat dan sumber belajar tidak bisa menggantikan guru sepenuhnya, artinya media tanpa guru suatu hal yang mustahil dapat meningkatkan kualitas pengajaran.

Salah satu jenis media pengajaran atau alat bantu pengajaran adalah lembar kerja siswa atau juga disebut sebagai worksheet (Mangelep, 2017; Yulius Irwan, Yerizon. 2017). Worksheet merupakan sarana pendukung pelaksanaan rencana pembelajaran yang berisi informasi maupun pertanyaan-pertanyaan yang prinsip dan aplikasi konsep atau prinsip. Secara konseptual worksheet merupakan alat untuk membuat siswa mengingat kembali materi yang pernah diperolah. Worksheet juga bisa berisi beragam soal untuk melatih berpikir siswa. Guru menyajikan soal dalam worksheet tersebut untuk diselesaikan oleh siswa.

Selain itu juga worksheet dapat digunakan untuk mengevaluasi hasil belajar. Guru dapat menggunakan worksheet untuk mmeriksa pemahaman siswa terhadap materi yang disampaikan. Worksheet berfungsi di antaranya sebagai berikut: 1) Menyusun materi sesuai dengan tujuan yang ingin dicapai; 2) Merumuskan langkah belajar siswa; 3) Memberikan tugas belajar siswa secara terpadu.

Keunggulan worksheet untuk digunakan dalam pembelajaran yaitu: a) mudah untuk digunakan baik dimanapun maupun kapanpun; b) dapat mengembangkan kemampuan siswa untuk belajar tentang fakta dan menggali prinsip yang disertai dengan argumentasi; c) worksheet dapat menyajikan kata-kata, angka-angka, notasi, gambar dua dimensi, serta diagram (Sudjana \& Rivai, 2010; Afriansyah, 2013; Utomo, Rahman, \& Fikrati, 2020). 
Keunggulan worksheet yang merupakan media pembelajaran ini akan membuat pembelajaran menjadi menyenangkan di kelas. Beberapa penelitian terkait media, pembelaran yang menyenangkan telah dilakukan oleh peperapa peneliti terdahulu. Hasil menunjukkan bahwa adanya media dapat meningkatkan hasil belajar serta pembelajaran yang menyenangkan akan membuat hasil belajar siswa meningkat (Aditya, 2018; Arimurti, Praja, \& Muhtarulloh, 2019; Istiqomah \& Prihatnani, 2019; Karimah, Rusdi, \& Fachruddin, 2017)

Berdasarkan masalah yang ada serta manfaat dan keunggulan worksheet membuat peneliti tertarik untuk melakukan penelitian untuk melihat pengaruh penggunaan worksheet terhadap hasil belajar di sekolah menengah.

\section{Metode}

Secara umum penelitian ini bertujuan mengetahui adanya pengaruh penggunaan media worksheet terhadap hasil belajar siswa kelas VIII. Sesuai dengan tujuan penelitian, rancangan yang akan digunakan dalam penelitian ini adalah kuantitatif. Populasi dalam penelitian ini adalah seluruh siswa kelas VIII MTs Salafiyah Syafi'iyah Tebuireng Jombang. Sedangkan pemilihan sampel diambil secara acak dari kelas yang ada. Hal ini dilakukan karena setiap kelas di kelas VIII memiliki kemampuan yang sama sehingga memiliki peluang yang sama untuk dijadikan sampel. Sampel dalam penelitian ni adalah siswa kelas VIIIA yang berjumlah 31 siswa.

Instrumen dalam penelitian ini adalah soal tes. Soal yang digunakan berupa soal uraian tentang bangun ruang kubus dan balok. Soal ini digunakan untuk mengetahui pemahaman siswa dalam bangun rang kubus dan balok, sehingga dapat diketahui ada atau tidaknya pengaruh penggunaan media worksheet terhadap hasil belajar siswa. Sebelum soal tes ini digunakan untuk mengambil data, maka sebelumnya soal tes ini divalidasi terlebih dahulu dengan menggunakan validasi ahli. Artinya peneliti meminta bantuan kepada ahli matematika dan ahli pendidikan untuk memvalidasi instrumen yang akan digunakan peneliti. Dalam penelitian ini, tes dilaksanakan pada saat pre-test dan saat post-test. Pre-test diberikan kepada siswa saat sebelum mendapatkan pembelajaran dengan media worksheet. Sedangkan post-test diberikan kepada siswa saat sudah mendapatkan pembelajaran dengan dengan media worksheet.

Analisis data dalam penelitian ini dimulai dengan uji normalitas. Uji normalitas bertujuan untuk mengetahui distribusi data dalam variabel yang akan digunakan. Data yang baik dan layak digunakan dalam penelitian adalah data yang berdistribusi normal. Selanjutnya setelah data berdistribusi normal, dilanjutkan dengan uji hipotesis 
menggunakan statistik uji-t dengan $\alpha=$ 0,05 .

\section{Hasil dan Pembahasan}

Instrumen yang digunakan divalidasi menggunakan uji validasi ahli. Uji validitas dilakukan peneliti dengan memberikan soal dan worksheet kepada dua orang dosen matematika untuk dilakukan uji validasi mengenai bahasa dan isi. Hasil validasi menunjukkan bahwa soal yang digunakan telah valid dan layak digunakan. Peneliti melanjutkan dengan memberikan pre-test kepada siswa kelas VIII sebagai sampel di awal pembelajaran, dilanjutkan dengan melakukan pembelajaran dengan media worksheet dan diakhiri dengan post-test.

Uji normalitas adalah langkah pertama dalam teknik analisis data, karena sebelum tes diuji $t$, tes tersebut harus diketahui berdistribusi normal terlebih dahulu. Dalam menghitung uji normalitas, peneliti menggunakan uji Kolmogorov Smirnov pada program SPSS versi 20 for windows yaitu sebagai berikut:

Tabel 1.

Hasil uji normalitas

\begin{tabular}{|c|c|c|c|}
\hline \multicolumn{4}{|c|}{ One-Sample Kolmogorov-Smirnov Test } \\
\hline & & pretest & posttest \\
\hline $\mathrm{N}$ & & 31 & 31 \\
\hline \multirow{2}{*}{$\begin{array}{l}\text { Normal } \\
\text { Parameters }{ }^{a, b}\end{array}$} & Mean & 74,74 & 78,10 \\
\hline & $\begin{array}{l}\text { Std. } \\
\text { Deviation }\end{array}$ & 23,580 & 21,735 \\
\hline \multirow{3}{*}{$\begin{array}{l}\text { Most Extreme } \\
\text { Differences }\end{array}$} & Absolute &, 169 & ,192 \\
\hline & Positive &, 154 & 157 \\
\hline & Negative &,- 169 &,- 192 \\
\hline \multicolumn{2}{|c|}{ Kolmogorov-Smirnov Z } &, 942 & 1,068 \\
\hline \multicolumn{2}{|c|}{ Asymp. Sig. (2-tailed) } & ,337 & ,204 \\
\hline \multicolumn{4}{|c|}{ a. Test distribution is Normal. } \\
\hline
\end{tabular}

b. Calculated from data.

Pada tabel One-Sample KolmogorovSmirnov Test terlihat bahwa Asymp.Sig.(2tailed) pada sebelum diberikan perlakuan adalah sebesar 0,337 , sedangkan pada sesudah perlakuan diberikan adalah sebesar 0,204. Hal tersebut menunjukkan bahwa kedua data tersebut berdistribusi normal karena Asymp.Sig.(2-tailed) pada keduanya lebih dari $\alpha$, yaitu lebih dari 0,05 . Selanjutnya peneliti melakukan uji hipotesis dengan uji-t sebagai berikut:

Tabel 2.

Hasil uji hipotesis

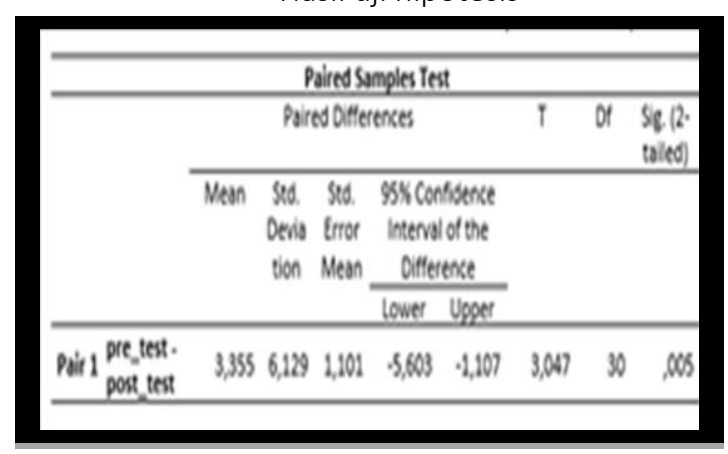

Berdasarkan hasil perhitungan dengan menggunakan program SPSS versi 20 for windows, diperoleh taraf signifikasi (2tailed) adalah sebesar 0,005. Nilai ini kurang dari tingkat signifikansi yang telah ditentukan yaitu sebesar 0,05. Dan nilai $t$ hitung adalah sebesar 3,047, nilai ini lebih besar dari t tabel yaitu 1,697. Sehingga data tersebut mengakibatkan penolakan pada $H_{0}$ tetapi dengan penerimaan $H_{1}$. Maka dapat disimpulkan terdapat pengaruh hasil belajar siswa setelah menggunakan media worksheet. Penelitian ini menjawab pertanyaan penelitian yaitu 
terdapat pengaruh media worksheet terhadap hasil belajar siswa.

Hal ini menunjukkan bahwa media worksheet memberikan dampak perubahan terhadap hasil belajar siswa menjadi lebih baik. Hasil penelitian ini juga sesuai dengan penelitian sebelumnya yang menyatakan bahwa penggunaan media pembelajaran salah satunya adalah lembar kerja dapat membuat hasil belajar matematika siswa meningkat karena siswa lebih mengerti dan materi lebih tahan lama dalam ingatan siswa (Aditya, 2018; Astuti \& Sari, 2017; Karimah dkk., 2017).

\section{Penutup}

Berdasarkan uraian di atas, maka pertanyaan pada rumusan masalah dapat terjawab, yaitu terdapat pengaruh penggunaan media worksheet terhadap hasil belajar siswa. Hal tersebut dapat dilihat pada perhitungan uji-t menggunakan program SPSS versi 20 for windows, pada perhitungan dengan menggunakan program SPSS versi 20 for windows diperoleh, taraf signifikansi (2tailed) hasil belajar siswa adalah sebesar 0,005 . Nilai ini kurang dari taraf signifikansi yang telah ditentukan yaitu sebesar 0,05. Dan nilai t hitung adalah sebesar 3,047 dan nilai tersebut lebih besar dari nilai $t$ tabel. Sehingga data tersebut mengakibatkan penolakan pada $\mathrm{H}_{0}$ dan merupakan penerimaan $\mathrm{H}_{1}$.

Kesimpulan penelitan ini adalah adanya pengaruh penggunaan media worksheet terhadap hasil belajar siswa. Sehingga media worksheet disarankan dapat digunakan dalam proses pembelajaran karena berpengaruh terhadap hasil belajar siswa. Selain itu, disarankan bagi pembaca atau peneliti selanjutnya untuk melakukan penelitian terkait pengembangan media pembelajaran worksheet. Pengembangan media worksheet tersebut dapat memperhatikan tingkat kognitif siswa, sehingga media dapat diterapkan dengan baik dan memberikan hasil untuk membantu siswa dalam memahami materi. Selain itu diperlukan penelitian terkait dengan materi matematika yang lain sehingga agar media worksheet yang dihasilkan dapat beragam materi.

\section{DAFTAR PUSTAKa}

Aditya, P. T. (2018). Pengembangan Media Pembelajaran Matematika Berbasis Web Pada Materi Lingkaran Bagi Siswa Kelas VIII. Jurnal Matematika Statistika Dan Komputasi, 15(1), 64. https://doi.org/10.20956/jmsk.v15i1.4 $\underline{425}$

Afriansyah, E. A. (2013). Design Research: Place Value in Decimal Numbers Using Metric System. In International Seminar on Mathematics, Science, and Computer Science Education MSCEIS, Universitas Pendidikan Indonesia (UPI) Bandung.

Afriansyah, E. A. (2016). The Use of Realistic Approach to Enhance Students' Mathematical ProblemSolving Skills. In International 
Conference on Elementary and Hodiyanto, H., Darma, Y., \& Putra, S. R. S. Teacher Education ICETE.

(2020). Pengembangan Media Pembelajaran Berbasis Macromedia Flash Bermuatan Problem Posing terhadap Kemampuan Pemecahan Masalah Matematis. Mosharafa: Jurnal Pendidikan Matematika,9(2), 323-334.

Arimurti, I., Praja, E. S., \& Muhtarulloh, F. (2019). Desain Modul Berbasis Model Discovery Learning untuk Kemampuan Pemahaman Matematis Siswa. Jurnal Pendidikan Matematika, 8(3), 459470.

Astuti, A., \& Sari, N. (2017). Pengembangan Lembar Kerja Siswa (Lks) Pada Mata Pelajaran Matematika Siswa Kelas X Sma. Jurnal Cendekia: Jurnal Pendidikan Matematika, 1(2), 13-24.

https://doi.org/10.31004/cendekia.v1i $\underline{2.16}$

Florayu, B., Isnaini, M., \& Testiana, G. (2017). Pengaruh Penggunaan Media Pembelajaran Komik terhadap Peningkatan Hasil Belajar Matematika Siswa Kelas VII di Sekolah Menengah Pertama Negeri 10 Palembang. Mosharafa: Jurnal Pendidikan Matematika, 6(1), 45-56.

Herawati, L., \& Nurhayati, E. (2019).

Eksperimentasi Model Pembelajaran Cooperative Script untuk Melatih Kecakapan Akademik Siswa. Mosharafa: Jurnal Pendidikan Matematika, 8(1), 131-142.

Iffah, J. D. N., Sutawidjaja, A., \& Sa'dijah, C. (2015). Zone of Promoted Action (ZPA) of Elementary School Teacher in Mathematics Learning.

Istiqomah, U., \& Prihatnani, E. (2019). Peningkatan Hasil Belajar dan Sikap Siswa terhadap Matematika melalui Joyful Learning Mosharafa: Jurnal Pendidikan Matematika, 8(3), 471482. Retrieved from https://journal.institutpendidikan.ac.i d/index.php/mosharafa/article/view/ mv8n3_11

Karimah, A., Rusdi, R., \& Fachruddin, M. (2017). Efektifitas media pembelajaran matematika menggunakan software animasi berbasis multimedia interaktif model tutorial pada materi garis dan sudut untuk siswa SMP/Mts kelas VII. Jurnal Penelitian Pembelajaran Matematika Sekolah (JP2MS), 1(1), 9-13. https://doi.org/10.33369/.jp2ms.1.1.913

Kemendikbud. (2013). Permendikbud Nomor 65 Tahun 2013 Tentang Standar Proses. 2011, 1-13.

Lisnani, L., \& Asmaruddin, S. N. (2018). Desain Buku Ajar Matematika Bilingual 
Materi Bangun Datar Menggunakan Pendekatan PMRI Berkonteks Kebudayaan Lokal. Mosharafa: Jurnal Pendidikan Matematika,7(3), 345356.

Luritawaty, I. P. (2019). Pengembangan Kemampuan Komunikasi Matematik melalui Pembelajaran Take and Give. Mosharafa: Jurnal Pendidikan Matematika, 8(2), 239-248.

Ma'ruf, A. H., Syafii, M., \& Kusuma, A. P. (2019). Pengaruh Model Pembelajaran Mind Mapping Berbasis HOTS terhadap Motivasi dan Hasil Belajar Siswa. Mosharafa: Jurnal Pendidikan Matematika,8(3), 503514.

NCTM. (2000). Principles and Standards for School Mathematics. The National Council of Teachers of Mathematics, Inc.

Novotná, Jarmila, Eisenmann, P., Přibyl, J., Ondrušová, J., \& Břehovský, J. (2012). Problem Solving in School Mathematics Based on. Journal on Efficiency and Responsibility in Education and Science, 7(1), 1-6. https://doi.org/10.7160/eriesj.2013.0 70101.Introduction

Nst, M. N., \& Rahmi, R. (2017). Pengaruh Penerapan Model Pembelajaran Berbasis Masalah disertai Teknik Berikan Uangnya terhadap Hasil Belajar Matematika Siswa Kelas VIII SMPN 16 Padang. Mosharafa: Jurnal Pendidikan Matematika,6(2), 273278.
Nursyahidah, F., Saputro, B. A., Albab, I. U., \& Aisyah, F. (2020). Pengembangan learning trajectory-based instruction materi kerucut menggunakan konteks megono gunungan. Mosharafa: Jurnal Pendidikan Matematika, 9(1), 47-58.

Prabawati, M. N., Herman, T., \& Turmudi, T. (2019). Pengembangan Lembar Kerja Siswa Berbasis Masalah dengan Strategi Heuristic untuk Meningkatkan Kemampuan Literasi Matematis. Mosharafa: Jurnal Pendidikan Matematika, 8(1), 37-48.

Presiden RI. (2003). UU RI No 20 Th 2003 ttg Sistem Pendidikan Nasional. 1-33. https://doi.org/10.1007/s13398-0140173-7.2

Rahmatina, D. (2017). Penggunaan perangkat pembelajaran geometri ruang berbasis ICT untuk meningkatkan kemampuan berpikir tingkat tinggi mahasiswa. Mosharafa: Jurnal Pendidikan Matematika,6(1), 57-68.

Rizkianto, I., \& Santosa, R. H. (2017). Analisis buku matematika siswa SMP Kurikulum 2013. Mosharafa: Jurnal Pendidikan Matematika,6(2), 229236.

Robiana, A., \& Handoko, H. (2020). Pengaruh Penerapan Media UnoMath untuk Meningkatkan Kemampuan Komunikasi Matematis dan Kemandirian Belajar Siswa. Mosharafa: Jurnal Pendidikan Matematika, 9(3), 521-532. 
Setiawan, Y., \& Prihatnani, E. (2020). Perbandingan TAl dan NHT terhadap Hasil Belajar Trigonometri Ditinjau dari Kecerdasan Interpersonal. Mosharafa: Jurnal Pendidikan Matematika,9(2), 299310.

Sudjana, N., \& Rivai, A. (2010). Media Pengajaran.

Suharyono, E., \& Rosnawati, R. (2020). Analisis Buku Teks Pelajaran Matematika SMP ditinjau dari Literasi Matematika. Mosharafa: Jurnal Pendidikan Matematika,9(3), 451462.

Suwarsih, S. (2018). Meningkatkan Hasil Belajar Siswa tentang Perkalian dan Pembagian Bilangan Cacah melalui Alat Peraga. Mosharafa: Jurnal Pendidikan Matematika,7(3), 433444.

Utomo, E. S., Rahman, F., \& Fikrati, A. N. (2020). Eksplorasi Penalaran Logis Calon Guru Matematika Melalui Pengintegrasian Pendekatan STEM dalam Menyelesaikan Soal. Mosharafa: Jurnal Pendidikan Matematika, 9(1), 13-22.

Winkel. (2007). Psikologi Pengajaran. Media Abadi.

Yunita, A., Juwita, R., \& Kartika, S. E. (2020). Pengaruh penerapan model pembelajaran kooperatif tipe teams' games tournament terhadap hasil belajar matematika siswa. Mosharafa: Jurnal Pendidikan Matematika,9(1), 23-34.

\section{Riwayat Hidup Penulis}

\section{Dr. Jauhara Dian Nurul Iffah, M.Pd.}

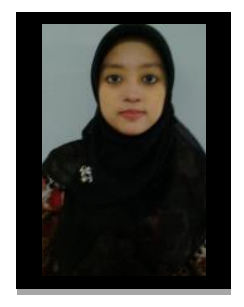

Lahir di Jombang, 22 April 1988. Staf pengajar di STKIP PGRI Jombang. Studi S1 Pendidikan Matematika STKIP PGRI Jombang, lulus tahun 2010; S2 Pendidikan Matematika Universitas Negeri Surabaya, lulus tahun 2012; dan S3 Pendidikan Matematika Universitas Negeri Malang, lulus tahun 2016. Publikasi artikel: Teacher's Rejected Promote Action (RPA) for Mathematics Teaching Practice in Class. 